\title{
NEWS AND NOTES
}

\section{MEDICOLEGAL}

\author{
What should a doctor tell?
}

\author{
BY OUR LEGAL CORRESPONDENT
}

A patient is threatening to sue a consultant physician for allegedly having failed to inform him that he was suspected of having stomach cancer, though he was told, correctly, that he had a gastric ulcer for which he received surgery. ${ }^{1}$ This incident comes on the heels of a recent court case in which a patient who had had a vasectomy and his wife sued his medical adviser on the ground of failure to warn of risk. $^{2}$ Some of the statements in the press and on television made in support of the patien with cancer suggest a desire to import into Britain the United States doctrine of "informed consent."

In the USA the doctrine of "informed consent" has so burdened the profession with costly litigation that in some states legislation has been introduced to modify the doctrine. The doctrine is founded on the proposition that it is for the patient, not the doctor, to determine what happens to a patient's body. From this it is argued that a doctor is under a special duty to make full disclosure of all risks, and without full disclosure the patient cannot give a valid consent to the treatment, leaving the doctor vulnerable to actions in either trespass or negligence.

Having seen where that doctrine leads, the English courts are certainly not going to accept it as part of the law of England, but there remains a conflict between two other views as to what the law ought to be. This conflict was considered by the Court of Appeal in February in the case of Sidaway $v$ board of governors of the Bethlem Royal Hospital and the Maudsley Hospital and others. ${ }^{3}$ Broadly, the choice is between on the one hand a standard of behaviour imposed by the courts on doctors, and on the other an acceptance that a doctor is not to be liable in damages if he conforms with the standards of one accepted body of medical practice, even if there is another body of medical opinion in strong disagreement.

\section{Test of negligence}

In the Sidaway case the trial judge (like other trial judges in recent years ${ }^{4}$ ) held that the test to be applied in considering whether a failure to warn was negligent was the same as the test in relation to complaints of negligence in diagnosis and treatment. In relation to diagnosis and treatment, the House of Lords has approved $^{6} 7$ the rule expressed in Bolam Friern Hospital Management Committee, ${ }^{8}$ but the House of Lords has never considered whether the same test should apply to failure to warn. In the Bolam case Mr Justice McNair said that when considering negligence, "The test is the standard of the ordinary skilled man exercising and professing to have that special skill. A man need not possess the highest expert skill; it is well established law that it is sufficient if he exercises the ordinary skill of an ordinary competent man exercising that particular art. . . There may be one or more perfectly proper standards, then he is not negligent. . . He is not guilty of negligence if he has acted in accordance with a practice accepted as proper by a responsible body of medical men skilled in that particular art. . . Putting it the other way round, a man is not negligent, if he is acting in accordance with such a practice, merely because there is a body of opinion who would take a contrary view. At the same time, that does not mean that a medical man can obstinately and pig-headedly carry on with some old technique if it has been proved to be contrary to what is really substantially the whole of informed opinion."

The Court of Appeal in the Sidaway case did not accept the Bolam test as giving the whole answer as regards the duty to warn, describing it as a test that enabled doctors to set their own standards. (The Bolam test clearly remains intact as regards complaints of negligence in diagnosis and treatment.) The Court of Appeal also rejected the United States and Canadian concept of "informed consent."

Because of their fears of a tendency for doctors to play down the risks in order to persuade patients to accept treatment that the doctors believed would be best for them, two judges of the Court of Appeal held that the definition of the duty to disclose should be a definition imposed by the courts on the doctors, but in considering whether the duty had been broken resort should be had to the Bolam test-the way in which other doctors discharge their duty.

The Master of the Rolls expressed himself in high flown language: "The definition of the duty of care is not to be handed over to the medical or any other profession. The definition of the duty of care is a matter for the law and the courts. They cannot stand idly by if the profession, by an excess of paternalism, denies their patients a real choice. In a word, the law will not permit the medical profession to play God." He defined the duty of disclosure as follows: "The general duty of a doctor to disclose information to his patient, as I would formulate it, is to take such action by way of giving or withholding information as is reasonable in all the circumstances of which the doctor knows or ought to know, including the patient's true wishes, with a view to placing the patient in a position to make a rational choice whether or not to accept the doctor's recommendation. I refer to the withholding of information as well as to giving it, because I recognise that there are cases in which the imparting of too much information may well hinder rather than assist the patient to make a rational choice. I also refer expressly to the patient's true wishes, because while I recognise that the patient has an overriding right to as little or as much information as he wishes and can absorb, it by no means follows that the expression of a wish for full information either generally or specifically represents the reality of the patient's state of mind. . . . Whether or not a particular doctor has or has not fallen below the requisite standard of care must be tested in the first instance by reference to the way in which other doctors discharge their duty - the Bolam test." Lord Justice BrowneWilkinson took a somewhat similar approach, but Lord Justice Dunn, the third judge of the Court of Appeal, dissented. He saw no reason in principle to distinguish between diagnosis and treatment and warning of the risks.

\section{Opinions on decision}

Although the decision of the majority of the Court of Appeal has found favour with many lawyers, it may well not find favour with the House of Lords. If the approach of Lord Justice Dunn is eventually adopted it will not reduce subscriptions to the medical protection societies but it will at least avoid encouraging their increase.

The same could not be said of the decision of Mr Justice Peter Pain in Thake $v$ Morris. ${ }^{2}$ A husband and wife sued a surgeon for damages for breach of contract to perform a vasectomy operation. They were evidently private patients. The judge held that the operation was performed successfully and competently but through no fault of the surgeon late recanalisation occurred and the female plaintiff conceived their sixth child.

The judge held that the surgeon had not warned the plaintiffs that there was a small risk of the operation reversing itself, though the surgeon apparently admitted that he usually gave such a warning. On the other hand, the surgeon had made it clear that the operation was irreversible. Instead of considering whether either the law or the standards of the profession required the surgeon to warn of the small risk of late recanalisation, the judge allowed himself to be led into the sphere of contract in what appear to have been somewhat artificial terms. The judge held that while the surgeon had not intended to guarantee the husband's sterility, on a true construction of both the oral and the written terms of the 
contract, in the absence of the warning which the surgeon usually gave as to the natural reversal, the surgeon had contracted to make the plaintiff husband irreversibly sterile. As he had not made the husband irreversibly sterile he was liable in damages. The judge went on to hold that there is no general rule of public policy that damages could not be awarded in respect of the birth of a healthy child, but that is another story.

Lawyers are not surprised that a contract can be made which is contrary to the unexpressed inner intentions of one party: after all, "consensus ad idem" is rarely translated into the language of mortals. But those who have been accused of playing God may fail to appreciate the subtlety. The lesson may be that surgeons who feel it necessary to emphasise irreversibility of vasectomy by humans (though not perhaps by microsurgeons of the near future) should also mention the possibility of divine intervention by recanalisation.

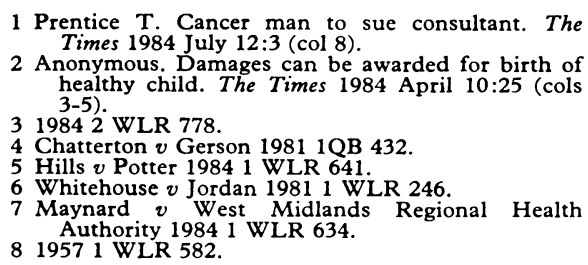
Times 1984 July 12:3 (col 8).

2 Anonymous. Damages can be awarded for birth of healthy child. The Times 1984 April 10:25 (cols 3-5). WLR 778.

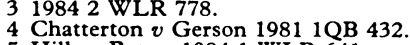

5 Hills $v$ Potter 19841 WLR 641

Whitehouse $v$ Jordan 19811 WLR 246.

Anth 1957 1 WLR 582.

\section{Helping the community to care}

The government is to make $£ 10.5 \mathrm{~m}$ available over the next three years to help volunteers, families, and others to care for people who need support. The new scheme, which has recently been announced by $\mathrm{Mr}$ Fowler, is to be called "Helping the community to care," and the commitment of funds is aimed at improving community care for the chronically sick, the elderly, and the mentally handicapped by assisting those who currently provide this care. Arrangements for funding projects will be worked out in detail with the voluntary bodies participating in the programme.

\section{Surveillance of AIDS}

Since the surveillance report issued at the end of April (10 May, $p$ 1542), nine further cases of the acquired immune deficiency syndrome have been accepted by the Communicable Disease Surveillance Centre as fulfilling the criteria for case definition. The total number of cases meeting these criteria is now 51 (47 men, three women, one sex not given); 28 of these patients have died.

The social services committee has recently published its third report, Perinatal and neonatal mortality report: follow up for the session 1983-4, and this may be obtained from HMSO, price $£ 9 \cdot 15$. The report says that the perinatal mortality has fallen, and continues to fall, from 15.5 per 1000 births in 1978 to 11.3 in 1982 . Neonatal mortality has fallen from $8 \cdot 7$ per 1000 births to 6.3 in the same period. Nevertheless, the rate in the United Kingdom still lags behind that in other countries (especially Scandinavia), and the wide variation in regional rates and social class differences remain.

\section{Cancer in west Cumbria- the Black report}

The report of the independent advisory group set up under the chairmanship of Sir Douglas Black to investigate the possible increased incidence of cancer in west Cumbria has just been published. The group was set up to investigate the allegations made in a television programme (1 November 1983) of a link between a cluster of cases of young people with leukaemia and other cancers in the village of Seascale near the Windscale plant for reprocessing nuclear fuel on British Nuclear Fuel's Sellafield site. The group concludes that - taking west Cumbria as a whole-the mortality from childhood cancer is near the national average. Nevertheless, Seascale had the third highest rate of lymphoid malignancy during 1968-82 in children under 15 years in one study, and this excess was entirely due to an increased incidence of leukaemia. The group concludes, however, as a result of its calculations, that there is little support for the view that the radiation released from Sellafield was responsible for the observed incidence of leukaemia in Seascale and its neighbourhood. It also emphasises that there is no evidence that there is any general risk to health for children or adults living near Sellafield when compared with the rest of Cumbria.

The report ends with a list of recommendations that have been made in the interests of enhancing public safety. These include recommendations that a study should be carried out on the records of those cases of leukaemia and lymphoma that have been diagnosed among young people up to the age of 25 years resident in west Cumbria, and that these cases should be compared with suitable controls in respect of possible risk factors; that a study should be carried out of the records of all children born since 1950 to mothers resident in Seascale at the time of birth; that more attention should be concentrated on measuring the dose of radiation received by people living in west Cumbria; and that particular attention should be paid to the discharges from the Sellafield site. Full details of the inquiry and its conclusions and recommendations are given in the report Investigation of the possible increased incidence obtained from HMSO price $£ 6 \cdot 70$.

\section{COMING EVENTS}

International Conference on Infection ControlMultidisciplinary conference organised by the Infection Control Nurses' Association of Great Britain, 17-21 Buckingham Road, Kingston upon Thames, Surrey. Buckingham Road
(Tel 014560304 .)

Institute of Obstetrics and Gynaecology-Details of symposia "Modern practice in gynaecological malignancy, 20-21 September, and "The management of haematological problems in pregnancy," 5 October, and a teach in for senior registrars "Recent advances in obare available from the symposium secretary of the institute, Queen Charlotte's Maternity Hospital, Goldhawk Road, London W6 0XG. (Tel 01-741 8351 ext 15.)

British Association of Trauma in Sport-Meeting "Internal organs in sport," 28 September, Birmingham. Details from

British Medical Association-Symposium for doctors and lawyers "Doctors and the courts," 24 October, London. Details from Andrew Bosi,
Tavistock Square, London WC1H 9JP.

Radiological Society of North America-70th scientific assembly and annual meeting, 25-30 November, Washington DC. Details from Lou Joseph of the society, 1415 W 22nd Street, Suite 1150, Oak Brook, Illinois 60521,

Kent Postgraduate Medical Centre at Canterbury -Course on "Medical statistics" for doctors sitting membership and fellowship examinations, 23 and 30
November, Canterbury. Details from the postgraduate November, Canterbury. Details from the postgraduate
administrator of the centre, Kent and Canterbury administrator of the centre, Kent and Canterbury
ext 4367.)

"Safety and health in diving operations"Symposium organised by the Commission of the European Communities and the European Diving Technology Committee, 7-8 May 1985, Luxembourg. Details from the secretariat of the Safety and Health Commission for the Mining and Other Extractive Industries, Commission of the European Communities,
Office C4/109, Jean Monnet Building, Krichberg, Office C4/109,
Luxembourg. "Tissue integration in oral and maxillofacial re1985 , Brussels. Details from Prof Dr D van Steenberghe, Faculty of Medicine, Catholic University Leuven, Kapucijnenvoer 7, B-3000 Leuven, Belgium.

18th Annual Hellenic Ophthalmological Congress
$-23-25$ May 1985, Athens. Details from the secretariat of cancer in west Cumbria, which may be

\section{People in the news}

Mr David McLeod has been appointed civil consultant in ophthalmology to the Royal Air Force.

Dr Eric S Blackadder has been appointed group medical adviser to BUPA from September 1984 .

of the congress, 10 Loukianou Street, GR 106 75, Second International Summer School on Second International Summer School on cal Medicine-3-7 June 1985, Padua. Details from Professor $C$ Cobelli, Department of Electrical Engineer6 A, 35131 Padova, Italy, or Dr E R Carson, Research A , 351 Padova, Italy, or Dr E R Carson, Research City University, Northampton Square, London ECIV OHB.

South Essex Postgraduate Medical Centre-Details and copies of the programme to December are available Basildon, Essex SS16 5NL. (Tel 02683911 ext 3360 )

\section{SOCIETIES AND LECTURES}

For attending lectures marked * a fee is charged or a ticket is required. Applications should be made first to the institutions concerned.

Wednesday 8 August

Royal Postgraduate Medical School-Stamp Lecture Theatre, $1015 \mathrm{am}$, medical staff round.

\section{Division meeting} to notify in advance the honorary secretary concerned.

Barnsley-At Postgraduate Centre, Barnsley District General Hospital, Wednesday 8 August, 7 pm, divisional meeting.

\section{Regional meeting} South East Thames Regional Hospital Junior
Staff Committee-At Joyce Green Hospital Postgraduate Centre, Tuesday 7 August, 7 pm. (Refreshments provided.)

\section{(C) British Medical Journal 1984}

All Rights Reserved. No part of this publication may be reproduced, stored in a retrieval system, or transmitted, in any form or by any means, electronic, mechanical, photocopying, recording or otherwise, without the prior
permission, in writing, of the British Medical fournal.

\section{BMA NOTICES}

Members proposing to attend meetings marked * are asked 